\title{
Coherence relations and information structure in English and French political speeches
}

\author{
Diana M. Lewis, Aix Marseille University
}

\begin{abstract}
This study addresses the marking of additive coherence relations in French and English political speeches. It is based on a balanced comparable corpus of ministerial political speeches spanning the late 1990s and early 2000s. Additive relations are expected to be the least marked relations, as where a discourse follows on naturally from what has gone before, coherence is easily assured by continuity intonation, a discourse continuity marker such as English 'and', or simple juxtaposition. Density and variety of additive markers are found to be much greater in the French speeches compared with the English, where additive relations are more often left implicit, resulting in quite different discourse patterns. The role of markers is illustrated by a case study comparing the roles of en effet and its dictionary equivalent indeed, which are found to function differently. The findings arguably reflect the greater distance between literary and conversational French than is the case for English. At the same time, the higher frequency of a number of the French markers seems to go along with greater grammaticalization towards rhetorical 'presentational' functions.
\end{abstract}

Keywords: French-English, discourse marking, additives, political discourse, grammaticalization, bleaching.

\section{Introduction}

As has been observed in a number of contrastive studies of French and English (such as Chuquet and Paillard 1987, Guillemin-Flescher 1981), there appear to be significant differences in the patterns of discourse marking between the two languages. There has been little agreement, however, on the nature of such differences. While some have argued that markers of discourse coherence seem to be more necessary in English than in French (v. Gallagher 1995; Mason 2001), others have claimed that French has a preference for a greater density of discourse marking (e.g.. Fetzer and Johansson 2010 on causation marking).

This paper takes a look at discourse marking in the genre of political speeches, a genre of written-to-be-spoken language that is broadly-speaking persuasive in intent. The study is based on a French-English comparable corpus of speeches. 
The paper is organized as follows. Section 2 discusses the additive coherence relation in the context of discourse coherence. Section 3 gives an overview of the genre-specific comparable corpus on which the study is based - political speeches - and describes the procedures. The findings on additive markers across the French and English speeches are presented in Section 4. Section 5 focuses on the uses of two additive markers that are commonly given as 'dictionary equivalents': French en effet and English indeed. The implications of the findings are discussed in the concluding section 6.

\section{Discourse coherence, information structure and additive relations}

Discourse coherence concerns the level at which the speaker, putting together her discourse, needs to enable the hearer to build an ongoing representation where each upcoming 'idea' - theme or proposition - finds its place. Information structure refers here to thematic progression, in the sense of structuring given and new information, as well as informational salience: means used by the speaker to foreground or background ideas, creating an information contour for the discourse.

Both coherence relations and information structure may be encoded in some linguistic device (such as prosodic pattern, lexical expression/construction or syntactic structure /construction), or may be left implicit for the hearer/reader to pragmatically infer. Some particular linguistic device may mark simultaneously a coherence relation and an information structural relation. In fact, some approaches to discourse tie the two together so that each coherence relation has an inherent information contour or grounding relation. This is the case, for instance, of Rhetorical Structure Theory (RST) (Mann and Thompson 1986). Others, such as Relational Discourse Analysis (RDA) (Oberlander and Moore 2001), distinguish 'semantic' coherence relations from 'functional' information structure.

Coherence relations (also known as discourse relations or rhetorical relations) include such notions as 'contrast', 'concession', 'result', 'elaboration', 'exemplification', 'addition', 'justification' and so on. They refer to the various ways in which the segments (or groups of segments) of a text or discourse fit into the rest of the text or discourse; that is, how each part relates to the parts that precede and follow it, and thus contributes to the overall meaning of the text.

These types of meaning can themselves be thought of as propositional. (In fact, they are referred to by Mann and Thompson (1986) as 'relational propositions', an area of meaning that is relatively grammaticalized into particles and adverbs, but which can also be 'propositionalized'.) Attempts to draw up empirically satisfactory taxonomies of coherence relations, using labels such 
as the ones above (contrast, concession, etc.), have foundered on three main difficulties: the issue of constraining the number of relations, the degree to which the taxonomy is hierarchical and the relationship between coherence and information structure. Moreover, each language will have its own network of relations depending on the way relations are typically drawn in the language in question. We do not adopt a taxonomic approach here; descriptions of relations in sections 4 and 5 are not to be interpreted as labels belonging to a particular taxonomy of predefined coherence relations, but simply as indications of the types of meaning expressed in the corpus data.

For practical purposes, nevertheless, a working model is needed to delimit an area for investigation. The approach adopted here is to view relations as a consonant-dissonant cline from total or high consonance to low or zero consonance. High consonance occurs where the ideas or sets of ideas expressed in consecutive discourse segments co-exist happily, being wholly compatible with one another (e.g. reformulation, exemplification). High dissonance occurs where adjacent discourse segments express ideas that are wholly incompatible (e.g. polar opposites). (This model is comparable to Murray's (1997) model of continuous vs discontinuous relations; we prefer different terms to avoid confusion with Continuative relations, which Murry subsumes along with causal relations under 'continuous'.) Fig. 1 illustrates such a simple partial model.

\begin{tabular}{|l|l|l|l|l|l|l|}
\hline \multicolumn{7}{|l|}{ Consonant relations } \\
\hline addition & cause & [other relations] & concession & contrast & antithesis & [other relations] \\
\hline $\begin{array}{l}\text { Also,.. } \\
\text { For instance,.. }\end{array}$ & $\begin{array}{l}\text { Because .. } \\
\text { so that } . .\end{array}$ & & $\begin{array}{l}\text { although } . . \\
\text { Even then .. }\end{array}$ & But ... & on the contrary, .. & \\
\hline
\end{tabular}

Table 1. A partial simple model of discourse coherence relations

Relations may be explicitly marked or left implicit (v. Taboada 2009). Marking takes many forms, more or less grammaticalized: syntactic pattern, subordinating conjunction, nonsubordinating conjunction, adverb, adverbial phrase, clause, modal particle, and so on. Dedicated discourse markers are adverbial lexemes and phrases such as however, even so, besides, for instance, moreover, and similar expressions in other languages. A further function of many, if not all, discourse markers is to signal the relative informational salience of the discourse segment they attach to. They thereby help the hearer to appreciate the speaker's evaluation of the relative importance of the states of affairs related in the discourse. The expression of discourse coherence is thus both subjective, indicating the speaker's vision of how the ideas expressed inter-relate, and intersubjective insofar as the speaker must anticipate the expectations of the hearer.

The focus here is on the discourse marking of additive relations. An additive relation will be 
said to exist where a new idea in the upcoming discourse develops the topic of the preceding discourse and is compatible with the preceding idea(s); simply put, it is 'more in the same vein'. (This use of 'additive' differs from that of other authors such as Halliday (1994), for example.) The relation may be between two states of affairs ('content' use) or between two speaker arguments ('presentational' use); often both types of relation obtain between two ideas (cf Hasselgård 2014:72). A single occurrence of a discourse marker might therefore be interpreted as encoding a state-ofaffairs relation, an argumentational relation and an information structural relation. In (1), for instance, What's more can be interpreted as introducing an additional event and an additional speaker argument, as well as signalling that the upcoming event/argument is more salient (rhetorically stronger for the speaker) than the previous idea that it links to.

(1) if they had been cheating I would have known. What's more, I would have been the first to complain. [BNC CH7, newspaper]

The aim of the study is to compare the usages of additive coherence relation markers by speakers of the political speech genre in the two languages and to identify potential discourse constructions built around an additive coherence relation.

Consonant relations in general are expected to be less marked (for example, by a discourse marker) than dissonant relations. This is because 'coherence' in the lay sense excludes incompatibility: the bare assertion of two apparently incompatible ideas results in incoherence. Where a proposition may appear to the hearer to be either at odds with what went before or irrelevant to it, some marker is called for to at least acknowledge the counterexpectation. But where an idea follows on naturally and unsurprisingly, it will usually be enough to use discourse continuity intonation, a discourse continuity marker such as English 'and', or simple juxtaposition, for the coherence to be understood. This can be seen from example (1), where the removal of What's more does not render the sequence incoherent. As Patterson and Kehler point out, "the more difficult recovering the correct relation would be without a connective, the more necessary it is to include one" (2013:915). Additive markers are therefore more optional than markers of other relation types.

This notion of uneven marking of relations is compatible too with the uniformity of information density (UID) hypothesis, according to which predictability largely explains variability in reduction. That is, the more predictable an upcoming item is, the more likely it is to be reduced (phonetically, syntactically, discoursally) (Levy and Jaeger 2007). Ars and Demsberg (2012:84) apply this hypothesis to discourse marking and observe that easily inferable relations are on average 
marked more ambiguously than relations which are less expected, in a fashion that arguably reflects discourse-level information density smoothing.

\section{Data: the comparable corpus of political speeches}

The study is based on an English-French comparable corpus of around 760,000 words consisting of political speeches given during the late 1990s and early 2000s. All the speeches are given by politicians in government in the course of their ministerial duties. The genre of ministerial speeches, in the European context, is a fairly constrained one. The sociocultural parameters of the situations in which such texts are produced are well-defined and similar across the two languages, so that identifying comparable texts for a corpus is fairly straightforward. It is unidirectional public language - produced by the specialist few (the political figures and their assistants) and designed for reception by several constituencies, which can include, in addition to the immediate (often specialist) audience, other politicians, other governments, other institutions, the media and the wider public. A ministerial speech is typically written to be spoken and contains a few thousand words at most. It expounds policy, aims to impress and persuade, and seeks positive evaluation from its several audiences. But its ceremonial role is also important: a speech is an integral part of many ceremonial events and other regular gatherings in the calendar of each minister.

The comparable corpus on which the study of additive connectives is based contains around 375,000 words in each language. Size-matching the parts of a comparable corpus by number of words is, of course, a rough-and-ready way to proceed. As is well known, typological differences mean that written French text tends to be 'longer' than written English text. ${ }^{1}$ For pairs of translated texts, for instance, the French text tends to exceed the English by both mean word length and number of words per sentence. The present corpus is no exception, with the mean length of word in the French part 5.16 characters compared with 4.83 for the English part, and mean sentence length 25.3 words in the French compared with 19.9 words in the English. A more appropriate measure (one involving the number of opportunities for the target constructions to occur - cf. discussion in Holmes 1994: 30), might be the discourse segment or, for an unsegmented corpus, the sentence. But the English speeches being on average notably longer than the French ones, by both word and sentence counts, the smaller number of English speeches is somewhat counterbalanced by the larger number of English sentences (table 2). Frequencies are given in relation to word counts. Prosodic information is not available, the corpus speeches being written versions only. 


\begin{tabular}{|l|c|c|}
\hline & French part & English part \\
\hline No. of words to nearest 000 & 372,000 & 384,000 \\
\hline No. of speeches & 149 & 133 \\
\hline Average no. of words per speech & 2497 & 2910 \\
\hline Average no. of sentences per speech & 98 & 145 \\
\hline
\end{tabular}

Table 2. The English-French comparable corpus of political speeches

\section{Additive marking across English and French speeches}

Starting from lists of potential additive markers in French and English, an overall picture of marking was drawn up for the texts in the two languages. The lists of markers were drawn up following consultation of a variety of sources: Danlos et al (2015), Roze (2009), the digital resource Dictionnaire des synonymes français, Quirk et al (1985) and Roget's Thesaurus.

Discourse-connective and and et were excluded from the study as they typically mark discourse continuity rather than addition, and often precede markers of other coherence relations (cf. And yet, Et pourtant and so on). Donc and so were also excluded for being still inherently causal, though both can arguably also mark discoursal addition. The additive uses of the markers listed in table 3 were counted.

\begin{tabular}{|l|l|}
\hline French & $\begin{array}{l}\text { ainsi, aussi, d'ailleurs, d'autre part, de même, du reste, du reste, effectivement, également, en } \\
\text { effet, en fait, en outre, en plus, enfin, ensuite, finalement, par ailleurs, parallèlement, } \\
\text { pareillement, puis / et puis, qui plus est, surtout }\end{array}$ \\
\hline English & $\begin{array}{l}\text { additionally, again, also, and of course, as well, besides, equally, further, furthermore, here again, } \\
\text { in addition, in fact, in the same vein, in the same way, indeed, likewise, moreover, similarly, then, } \\
\text { thus, too, too, what is more }\end{array}$ \\
\hline
\end{tabular}

Table 3. Additive markers counted in the comparable corpus

Surprisingly, the frequency of besides, a fairly typical marker in English conversation and other genres (cf. Hasselgård 2014), was zero. The most frequent fifteen markers in each language are listed with their frequencies in fig. 1.

French speeches clearly contain more frequent and more varied additive marking than the English ones. Aussi, ainsi, également, enfin, en effet, par ailleurs, d'ailleurs, de même, en outre, [et] puis, d'autre part all occur at more than 10 per 100k words, in an additive function, across a range 

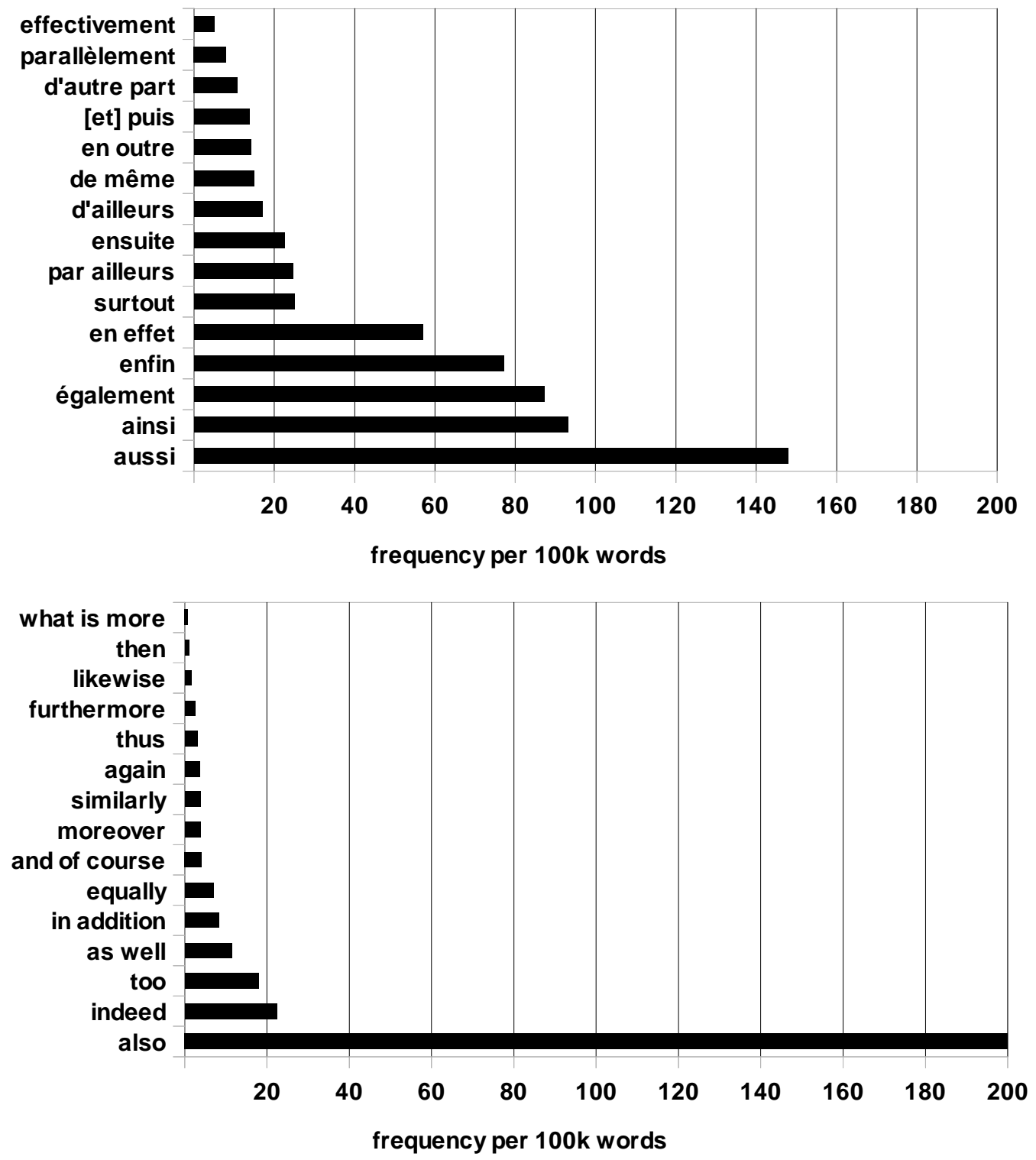

Fig. 1. Frequencies of the fifteen most frequent additive markers in the French and English speeches

of speakers. The English speakers, by contrast, rely largely on juxtaposition and on also; the only other frequent markers being too, indeed, and as well. English additive discourse markers such as in addition, moreover, similarly, thus, further[more], likewise, what is more, in fact, in the same way, here again, besides, etc. are rare ( $<10$ per 100k words). The use of the French additive markers can be viewed as helping to create, or as reflecting, a particular style of parallelism, using additive marking to pile up consonant propositions and create a layered, cumulative case. Each layer of ideas seems to add equal weight to the overall argumentation, but may be internally structured into more salient and less salient points. The English speakers, by contrast, rely more on juxtaposition and structural similarity to create argumentation that is less explicitly cumulative. 
Hobbs (1985) discusses parallelism as follows:

\begin{abstract}
"Considerations of coherence in general allow us to string together arbitrarily many parallel arguments. But it is a convention of argumentation for there to be just three, and those ordered by increasing strength. In political rhetoric, one also hears sequences of parallel statements, but for maximum effectiveness, they should be more than just the semantic parallelisms characterized by the theory of coherence. They should also exhibit a high degree of lexical and syntactic parallelism." (Hobbs 1985:27)
\end{abstract}

These devices are made quite explicit in the French speeches through both lexical and syntactic parallelism and the regular framing of arguments by discourse markers. This kind of parallelism is exemplified in (2), which shows the coherence markers (in bold, with the additives underlined) and the hierarchical structure (indentation).

(2) L'euro n'est pas un joujou [...]

L'euro c'est un projet politique [...]

L'euro c'est aussi un enjeu économique que, là aussi, je résumerai simplement [...]

L'euro c'est d'abord [...] un facteur de stabilité [...]

là aussi $[\ldots]$

L'euro c'est ensuite plus de sécurité [...]

Enfin créer l'euro c'est donner à la monnaie européenne une masse critique [...]

Voilà pourquoi l'euro est une chance [...]

N'est-ce pas d'ailleurs [...] [Juppé, 27/11/996]

'The euro is not a plaything ...

The euro is a political project ...

The euro is aussi an economic challenge that, là aussi, I will simply summarize ...

The euro is $\boldsymbol{d}^{\prime}$ abord ... a stabilising factor ...

là aussi ...

The euro ensuite means more security ...

$\underline{\text { Enfin }}$ the creation of the euro provides European currency with a critical mass ...

That is why the euro is an opportunity ...

Is it not true $\underline{\text { d'ailleurs }}$...'

English speeches tend to manifest a different style of parallelism altogether, as in (3). There 
is semantic parallelism here (underlined) in the repetition of the notion 'impact on Britain': a crescendo of impact from it matters through directly affect us to enormous disruptive effect on us. And there is structural and semantic parallelism (bold) in the three subordinate clauses even if .., whatever .. and even if... . The rhetorical cohesion is achieved without any discourse markers at all.

\section{It matters to Britain that EMU should succeed, even if we never join it.}

The emergence of a euro-zone in the middle of our largest market, the Single Market, will directly affect us in this country, whatever we do. We want EMU to be solid, durable and stable because a euro-zone would inevitably be our most important trading base. Already growth or recession on the continent feeds quickly into the UK economy.

If a euro-zone failed, the disruptive effect on us would be enormous, even if we were outside it.

[Clarke, 18/12/1996]

These speakers of French and English are using quite different rhetorical templates.

\section{En effet and indeed in the political speeches}

Both en effet and indeed seem to be particularly typical of the genre of speeches. And both, as sentence adverbials, are used overwhelmingly in the context of consonant discourse relations. Both are anaphoric, dependant for interpretation on a previous idea from a previous segment of discourse being accessible to the hearer. They can both, therefore, be characterized as typical or 'central' additive markers. Moreover, they are considered dictionary equivalents (e.g. Dictionnaire Le Robert $\&$ Collins 2013). We shall see below, however, that although their functions overlap, they cannot be considered functional equivalents in the context of political speeches.

To identify the probable functions of the discourse markers, the procedure was to interpret, independently of the marker, the degree of coherence and the most plausible type of relevance holding between the proposition in the host discourse segment and that in the previous discourse segment. This interpretation was then compared to the interpretation with the marker.

\subsection{Indeed}

Indeed is conventionally described as a modal epistemic adverb of certainty, with a transparent origin in the prepositional phrase in deed. Its development from PP to discourse marker is traced in 
Traugott and Dasher (2002: 160-164). Indeed is associated with formal registers and is more frequent (and differently distributed) in writing than in speech (191pmw vs 166pmw in the British National Corpus). At $221 \mathrm{pmw}$, then, the frequency in the political speeches is relatively high, in accordance with the formality of the genre.

Núñez Pertejo (2008), working with the ICE-GB corpus, identifies three functions of indeed: (i) as a speech-act adverb, (ii) as a narrow-scope adverbial modifier, and (iii) as a discourse marker which confirms or reinforces a preceding argument or assertion, this last being by far the most frequent use (2008: 725-731). Aijmer's (2008) analysis of indeed based on parallel corpora identifies it as a marker of emphasis, of confirmation, and as focalizing or intensifying. And Aijmer (2007:330) characterises indeed as further having "the social meaning speaker authority".

Table 4 shows the positions of indeed in the English speeches. The medial position is limited to clauses with be or an auxiliary. (While pre-V position is frequent for English -ly sentence adverbs like clearly and connectives like therefore, it seems to be avoided for modal adverbs such as indeed, in fact, at least, after all, etc. used as discourse markers. Where no other auxiliary is present, a doconstruction is used. Instances of such adverbials found pre-verbally (no Aux) in other corpora were rarely connective.)

\begin{tabular}{|l|l|}
\hline Position in the sentence & \% of occurrences \\
\hline Sentence-initial, including 4 x And indeed .. & $77 \%$ \\
\hline After Aux or be & $15 \%$ \\
\hline After Adj or Adv (constituent-final position) & $8 \%$ \\
\hline
\end{tabular}

Table 4. The position in the sentence of occurrences of 'indeed' in the English speeches $(n=85)$

The different functions of indeed apparent in the corpus correlate closely with position in the host (table 5). Indeed in both final and medial positions is a modal adverb. Final position corpus occurrences, after an AdjP or AdvP host, are all exemplars of the construction <very Adj|Adv indeed $>$, in which indeed combines with very to indicate 'extremely' (4).

(4) ..the rationale for having such a power is clear and we shall want to look at it very closely indeed. [Lloyd, 09/06/1997]

In medial position (5), indeed stresses the veracity of its host where there may have been doubt (cf. really, truly, definitely); it can be said to be counterexpectational. 

23/09/1997]

In this position indeed may also combine with an adversative marker to form a concessive construction <indeed $\mathrm{p}$, [adversative DM] q> as in (6), or with if to form a concessive-conditional construction (7). In these constructions it can also be described as counterexpectational.

(6) Companies are indeed observing those rules, but not always in a way which positively informs shareholders and employees, or responds to their concerns. [Becket, 04/03/1998]

(7) Who do you think should run such a bidding system, if indeed you are persuaded by its attractions? [Aitkin, 15/03/1995]

Initial occurrences, by contrast, are all discourse connective; and by virtue of this position, indeed acts as a presentative. The hosts are not all full clauses, as exemplified in (8).

(8) Hong Kong stands as a monument to what the human spirit can, indeed will, achieve .. [Rifkin, 12/02/1997]

In the great majority of cases (v. table 5), the indeed host is a wider, stronger claim than the preceding one. The examples in (9) are typical. In contexts such as (9a), the relation is usually expressed in French with au contraire (v. Lewis 2005:45-46).

(9) a. NATO has not collapsed. Indeed - the best test of success - countries are queuing for membership. [Portillo, 05/12/1995]

b. The new government in Britain has a clear plan about how it intends to shape British foreign policy, and indeed to shape the world in which Britain lives. [Symons, 10/10/1997]

c. Hong Kong, as so often in its history, has defied the pessimistic smart Alecs. Indeed it has defied the odds. [Major, 04/03/1996]

In a few instances, the indeed host largely repeats the previous idea (10), or provides some detail or additional information about it that exemplifies, clarifies or justifies it (11). These contexts are the closest to the French contexts in which en effet is found. 
(10) IT offers immeasurable oppportunities to bring new, more efficient ways of delivering public services shaped to meet the needs of the customer. Indeed, IT presents an amazing opportunity to rethink fundamentally the way that Government provides services [Freeman, 28/10/1996]

(11) ..trade has always been the backbone of Anglo-Tunisian relations. Indeed, our first formal treaty in 1662 was about commerce. [Hanley, 09/01/1997]

Table 5 summarizes the distribution of indeed in the corpus.

\begin{tabular}{|l|l|l|r|c|}
\hline Position & Construction & Function & $\mathrm{n}=$ & $\%$ \\
\hline Host-final & very $\{$ Adj|Adv indeed & intensification & 7 & 8 \\
\hline Medial (post-Aux) & Subj Aux indeed V C & counterexpectation contexts & 13 & 15 \\
& & $\begin{array}{l}\text { (a) emphasis } \\
\text { (b) concession } \\
\text { (c) concessive-conditional }\end{array}$ & 8 & \\
& & rhetorical salience & 2 & \\
\hline Initial & p indeed $\mathrm{q}$ & (a) q is wider/stronger claim than p & 54 & \\
& & (b) q gives detail of p & 65 & 77 \\
& & (c) unclear occurrences & 5 & \\
\hline
\end{tabular}

Table 5. The functions of 'indeed' in the English corpus ( $n=85)$

In the ICE-GB corpus, Aijmer (2008: 117-119) found indeed to be more than twice as frequent in parliamentary debates and non-broadcast speeches (respectively 80.9 and 61.9 per 100 kwords) as in other genres and in those contexts it typically conveys rhetorical strengthening: "The function of indeed in parliamentary debates is to strengthen the assertion or argument (the rhetorical use of indeed) by adding more certainty especially in the combination and indeed" (Aijmer 2008: 117). Simon-Vandenbergen and Aijmer (2007) likewise note that "'x and indeed $y$ ' ... implies that $y$ is informationally stronger than $x^{\prime \prime}(2007: 120)$. The findings from the present political speeches corpus bear this out, though the frequencies are much lower at 22 per 100 kwords.

While operating as an epistemic modal adverb, emphasizing veracity, indeed, like some other epistemic adverbs, can be used dialogically, persuasively, depending on the assumptions the speaker makes about the hearer's state of knowledge and beliefs. This rhetorical function depends on indeed being seen in the wider context of a discourse construction, $\langle\mathrm{p}$ indeed $\mathrm{q}>$ where $\mathrm{q}$ is a wider or stronger claim than $\mathrm{p}$, set in a wider-still context of a thematic chunk of discourse. 


\subsection{En effet}

En effet in present-day French, as noted by Charolles and Fagard (2012: 137), is used exclusively as a lexicalized particle, or 'particule lexicalisée', which functions as a connective or discourse marker. It cannot be discourse-initial, but must have a previous idea to refer back to. Like indeed, en effet as a connective goes back a long way. It is attested already in the late fourteenth and early fifteenth centuries, considerably earlier than other, similar connectives and, again like indeed, the earliest widespread use seems to have been, as far as can be ascertained from available sources, in legal prose and in records, followed by philosophical prose (Bertin 2002: 47-48). Bertin suggests that en effet may have been in competition in Middle French with the declining epistemic adverb si, to which it offered a weightier and more substantive alternative, and which it may have gradually replaced (2002: 48). It may therefore be an example of the grammaticalization cycle whereby a highly grammaticalized form, become eroded and/or bleached, is overtaken by a periphrasis, which then in turn undergoes further grammaticalization. En effet evolves from high-certainty epistemic sentence adverb to connective, a typical development cross-linguistically. It also occurs, from an early stage, as a complete dialogic turn of confirmation, again like indeed.

In the Speeches corpus, en effet occurs overwhelmingly in post-verbal (post-auxiliary where there is one) position (table 6).

\begin{tabular}{|l|l|}
\hline Position in the sentence & \% of occurrences \\
\hline Sentence-initial & $21 \%$ \\
\hline Pre-subject, after a sentence-initial adverbial & $3 \%$ \\
\hline Post-subject, before the finite verb & $2 \%$ \\
\hline Post-verb/auxiliary & $74 \%$ \\
\hline
\end{tabular}

Table 6. The position in the sentence of occurrences of 'en effet' in the French speeches $(n=210)$

This post-verbal (or post-auxiliary) position is also the most frequent position (over 70\%) for two other high frequency discourse markers in the corpus: également (87 per $100 \mathrm{kwords})$ and donc (122 per 100 kwords). By contrast, the less frequent de même (15 per 100 kwords) in just over half its occurrences is in initial position, just less than half being post-verb/auxiliary.

Using a corpus of literary texts, Schoonjans (2014) shows that, in declarative sentences, this same post-verb/auxiliary position accounts for around $80 \%$ of high frequency markers such as donc, seulement, quand même and tout de même. Schoonjans likens this position in French to the wellknown 'middle field' of German modal particles (see also Schoonjans 2012 for similarities between 
French and German particles). Given this kind of data, it looks as though these high-frequency discourse markers may be at a relatively advanced stage of grammaticalization (in the broad sense), and may be part of an emergent discourse-level schematic construction in which there is a postverb/auxiliary 'slot' for the anaphoric marker.

In the speeches corpus, the en effet host is a full clause in every case, unlike indeed. En effet occurs mainly in declaratives, but also in interrogatives. The speeches being monologues, the interrogatives are, of course, rhetorical questions. When the en effet host (the segment to which it attaches) contains a speaker-attitude predicate, there can be some ambiguity as to whether the marker has (pragmatically) scope over the speaker attitude, over the following proposition, or both. The position of the discourse marker, along with the context, suggest that in most cases it is at least the speaker attitude and often both (12).

(12) L'action du gouvernement repose sur l'ouverture d'un débat public. J'ai en effet la conviction que les solutions ne peuvent être imposées d'en haut à la société. [Jospin, 25/08/1997]

'The government's actions depend on setting up a public debate. I am en effet convinced that solutions cannot be imposed on society from above.'

Previous work on en effet has identified a range of related functions, suggesting that it is polysemous. Charolles and Fagard (2012), for instance, argue that uses of en effet can be attributed to one of three functions: (i) confirmation of an idea expressed in the preceding cotext, most often in dialogue; (ii) confirmation of an expected event; (iii) justification or explanation of the previous idea. Rossari (2016) argues that the Justificative use of en effet emerges from its dialogic use: "L'adverbe signale l'approbation de ce qui a été énoncé précédemment et le segment p qui le suit donne une raison de cette approbation" (2016) ('The adverb signals approval of what has been said previously and the segment $\mathrm{p}$ that follows gives a reason for this approval'). Rossari (2016) further suggests that the dialogic origin of the Justificative usage may be in a truncated concessive: "La valeur justificative propre à l'emploi de en effet et effectivement dans certaines configurations monologiques coïncide avec un schéma concessif tronqué" ('The justificative sense of en effet and effectivement in certain monologic contexts matches a truncated concessive schema'). A dialogic concessive involves a three-element construction, $\left\langle\mathrm{p} \mathrm{p}^{1}, \mathrm{q}\right\rangle$, where an idea (p) (attributed to the hearer or a third party) is acknowledged and confirmed $\left(\mathrm{p}^{1}\right)$, but dispreferred or considered not relevant by the speaker compared with some following idea (q) that she wishes to promote (cf. Couper-Kuhlen and Thompson 2000). En effet in the political speeches does seem to share with 
Concession the notions of given information and of dialogic confirmation, as discussed below. But no evidence of a dispreferred idea that might suggest truncated concession was found.

In the majority of cases of en effet in the political speeches corpus, the host picks up on and elaborates in some way on the previous idea(s), to reformulate it (13), justify having expressed it (14), or provide evidence that it is true (15). But en effet often occurs with a less specific elaborative relation, especially a move from the general (in the previous idea) to the particular (in the host idea). This typically involves reiterating the thematic element of the idea and providing greater detail (16) and (17).

In (13) the same idea is expressed in both clauses. The effect of the discourse marker is to emphasize their equivalence; without it, 'a lot being at stake' might come across as stronger than 'particularly important'.

...ce texte dont nous débattons aujourd'hui revêt une importance particulière. L'enjeu est en effet de taille. [Guigou, 29/02/2000]

'The text we are discussing today is particularly important. What is at stake is en effet considerable.'

Example (14) illustrates the typical justification use, the en effet host being the justification for the speaker not going into detail.

(14) ...le collectif prévoit une diminution voisine de 3,3 milliards d'euros par rapport à la LFI, sur laquelle je ne m'étends pas : votre rapporteur général a en effet décrit l'ensemble des évolutions prévues par ce collectif de manière exhaustive dans son rapport écrit .. [Mer, 29/07/2002]

'.. the revised budget involves a reduction of around 3.3bn euros from the initial budget; I will not go into that in detail : your Rapporteur-general has en effet described all the changes involved in the revision thoroughly in his written report..

In (15), evidence for the first assertion is presented in the second. At the same time, the evidence provides a justification for making the first statement, so that evidence and justification are closely linked.

(15) je sais qu'il n'est point nécessaire de vous convaincre que la recherche universitaire doit aujourd'hui s'inscrire résolument dans un espace européen. Votre colloque annuel qui s'est tenu voici 2 mois à Bordeaux était en effet consacré pour une large part à la discussion de la comunication de la Commission intitulée "Vers un espace européen de la recherche ". [Schwartzenberg, 18/05/2000] 
'I know you do not need to be convinced that university research today must be firmly anchored in a European context. Your annual conference held two months ago in Bordeaux was en effet largely devoted to discussion of the Commission paper entitled "Towards a European research area".

The en effet host in example (16) can be interpreted as elaborating in more detail on what women point out; but also as explaining why new legislation is not the obvious answer or justifying the speaker's statement that it is not the obvious answer.

(16) Du point de vue même de ce que demandent les femmes, c'est-à-dire la justice et l'égalité, la création de dispositifs légaux ne va pas de soi, elles sont d'ailleurs nombreuses à le dire. Elles ne veulent pas en effet être des "femmes alibis" qui seraient choisies sur d'autres critères que la compétence. [Juppé, 11/03/1997] [116]

'From the point of view of what women are demanding, that is to say justice and equality, creating new legislation is not the obvious answer, as many of them point out. They do not want en effet to be 'token women' selected on criteria other than their competence.

In all, around 5\% of occurrences clearly involved Reformulation, 37\% justification and 3\% evidence. Overall, $40 \%$ involved a move from a more general idea to a more particular idea in the en effet host (17). Where a point the speaker wishes to make is split in two, so to speak, into a topicintroducing segment and an explanatory or enhancing segment, it is easy to see a dialogic echo, with a tacit response between the two conjuncts, followed by en effet acting as affirmation ('yes') and an elaborative, justificative, or explanatory sequel.

(17) a. Ce régime est plus sévère que celui de la loi de 1995. En effet, le seuil au dessus duquel les condamnations à une peine d'emprisonnement avec sursis simple ne sont pas amnistiées a été abaissé par rapport à la loi de 1995 : il passe en effet de neuf mois à six mois. [Perben, 23/07/2002]

'This regime is more severe than that of the 1995 act. En effet, the threshold beyond which 'simple' suspended sentences cannot be amnestied has been lowered from that of the 1995 act: it has gone en effet from nine months to six months"

b. ... vous vous inscrivez dans une de nos plus anciennes traditions. C'est en effet au milieu du XVIIIe siècle .. que les premiers prix du concours furent discernés .. [Darcos, 02/07/2002]

'.. you are joining of one of our most ancient traditions. It was en effet in the middle of the 18th century that the first competition prizes were awarded'

In one example in the corpus en effet might perhaps be interpreted as concessive (18), but it is not clear. One interpretation of (18) is that the use of en effet conforms to the elaborative pattern: 
the notion of paradox is introduced, then the paradox is specified; the two elements comprising the paradox are marked by 'd'un côté' and 'mais de l'autre' which together frame the contrast. Another is that the two contrasting elements are marked by 'd'un côté' and 'de l'autre', while 'en effet ... mais' frames a concession.

(18) J'ai évoqué tout à l'heure le paradoxe agricole de notre pays. Mais celui-ci se double d'un paradoxe rural. D'un côté en effet, nous assistons à un certain renouveau démographique de nos campagnes. Mais de l'autre, nos compatriotes ruraux s'interrogent devant la méconnaissance par la France urbaine de certaines spécificités de leur modes de vie ... [Gaymar,04/07/2002]

'I spoke just now about the agricultural paradox in our country. But there is also a rural paradox. On one hand, en effet, we are witnessing a certain demographic renewal in the countryside. But on the other hand, our rural compatriots are concerned that urban France is ignorant of the particularities of their way of life ...'

In several cases what is striking is the way en effet occurs as part of a series of discourse markers that together create a rhetorical frame for a chain of interlinked ideas, as seen in Section 4, each with its anaphoric marker. In (19) the en effet host is a simple repetition, after a parenthesis, of a previous proposition ('This law will be exemplary' - 'Our future law will be exemplary'). To maintain coherence, it needs to be marked as old information, the function of en effet here.

(19) Je ne souhaite pas que cette disposition ... puisse masquer le fait que la France, par l'adoption de ce projet de loi, sera l'un des pays les mieux armés pour lutter contre la corruption internationale.

Je me prononcerai donc en faveur de l'amendement [1] ...

Enfin, j'approuve également l'amendement [2] ...

Notre future loi sera ainsi exemplaire, et je tiens une fois encore à remercier votre Commission et Monsieur Jacky DARNE, votre rapporteur, pour son utile contribution à l'élaboration de ce dispositif législatif.

Cette loi sera en effet exemplaire, d'abord par son effet dissuasif ...

Elle traduira ainsi le souci de la France de combattre sans relâche ce fléau économique et social que constitue la corruption nationale et internationale. [Guigou, 29/02/2000]

'I do not want this provision to be able to conceal the fact that France, in passing this bill, will be one of the countries best equipped to fight international corruption.

I will donc vote in favour of amendment [1] ...

Enfin, I approve également of amendment [2] ... 
Our future law will ainsi be exemplary, and I would like once again to thank your Commission and Mr Jacky Darne, your rapporteur, for their useful contribution to the drafting of this legislative package.

This law will en effet be exemplary, first of all due to its disuasive effect ...

It will ainsi answer France's concern to fight relentlessly the economic and social scourge of national and international corruption.'

For many occurrences, then, more than one relation plausibly holds between the conjuncts; for others, there seems to be no relation other than continuity. We suggest that the range of contexts in which en effet occurs in the political speeches genre reflects its vagueness rather than polysemy. Across different context types, it implies consonance and helps validate or in some way reaffirms the previous idea.

To summarize, en effet links its host segment to the previous segment, thereby creating a two-segment discourse pattern. The en effet host expresses an idea that is entirely consonant with the previous idea, which it reformulates or expands on with a more particular, or, more rarely, a broader idea. There is a range of similar relations with which use of en effet is compatible, and its removal does not result in incoherence. The frequency and contexts of en effet point to its being highly bleached, and rather than consider that en effet is polysemous, it better fits these data to characterize it as vague: we can hypothesize that these relations are contiguous in conceptual space.

As mentioned above, en effet occurred in full clauses. In this genre, a theme is typically introduced in general terms in one clause and then fleshed out or expanded on in the next. Insofar as the en effet host provides the additional detail, it is informationally subordinate to the previous segment (a 'nucleus-satellite' relation typical of elaboration, in RST terms, or a 'core-contributor' relation in RDA terms). Oberlander and Moore (2001) cite corpus studies showing that, in English at least, a discourse marker is much less likely to be used when there is nucleus-satellite (corecontributor) order, since this order is easy to process, and marking is superfluous. All this suggests that there may be reasons other than coherence marking and/or information structure marking for such frequent occurrence of en effet. And when seen in wider rhetorical context, it appears that en effet forms part of a network of markers providing thematic continuity and lending a particular rhetorical rhythm to the discourse through parallelism.

Two discourse constructions for en effet can be identified in this genre: (i) <p En effet q> and (ii) the more frequent $\langle\mathrm{p} \mathrm{q}\rangle$ where $\mathrm{q}$ is $\langle$ Subj - V/aux - en effet - Compl $\rangle$. While the relation is the same for both ( $\mathrm{p}$ is any proposition and $\mathrm{q}$ is presented as confirming or expanding on $\mathrm{p}$ ), the information structure differs, reflecting that of the higher-level constructions (i) $<p$ DM $q>$ and (ii) 
$<\mathrm{p} \mathrm{q}>$ where $\mathrm{q}$ is $\langle$ Subj - V/aux - DM - Compl>. The regularity of the post-verb/auxiliary position, shared with other very high-frequency connectives, suggests the second is the more grammaticalized.

\subsection{Comparison}

Both en effet and indeed are modal adverbs that retain some epistemic sense but have now taken on discourse structuring functions too. Both are found overwhelmingly in contexts of elaboration in this genre.

Halliday describes 'elaboration' as where "one clause elaborates on the meaning of another by further specifying or describing it" (1994:225). In paratactic elaboration, the secondary (elaborating) clause may have one of three functions: (i) "to restate the thesis of the primary clause in different words, to present it from another point of view, or perhaps just to reinforce the message", (ii) to develop the thesis of the primary clause "by becoming more specific about it, often citing an actual example" and (iii) to clarify the thesis of the primary clause, "backing it up with some form of explanation or explanatory comment" (1994:226). This sense of elaboration comes close to matching the predominant political speech use of en effet, which is found in all three contexts.

Connective indeed is used more narrowly, either to present a stronger version of the same claim, or to make a further and stronger claim related to the first claim. Its initial position and parenthetical syntax are typically presentative. There is thus a significant difference in the information structuring functions of the two expressions, en effet marking its host as old or given information (from a new aspect or in more detail), while indeed introduces a new and more surprising claim (counterexpectation).

A second difference, as we have seen, is that en effet appears to be more grammaticalized than indeed, which ties in with its much greater frequency and its bleached semantics that allows it to occur in a wider range of contexts.

Finally, the markers should be seen in the context of the wider rhetorical patterns of the genre. En effet contributes, along with other markers, to a pattern of parallel ideas each explicitly linked to the previous discourse. The English speeches make more use of juxtaposition, so that indeed does not function as part of a network of markers. 


\section{Conclusion}

It has been seen that the overall effect of use of additive markers in French political speeches is to create even-paced stretches of discourse where each segment forms a link in a wellconstructed chain of arguments and where the hierarchical structures (the rhetorical dependencies) are transparent and conventional. One of these conventions is the regular, almost rhythmic use of additive discourse markers such as également, de même, en effet, ainsi, all occurring overwhelmingly in the same post-verb/auxiliary position in the host, acting as the 'hooks' attaching each segment to the previous discourse in a series of parallelisms. Metaphorically-speaking, these markers can be seen as pinning the content of the discourse to its rhetorical backcloth.

The use of dedicated connectives - for coordination, subordination and discourse connectivity - has been linked to literacy. Speakers conjoin fewer consituents than writers. Nonliterate languages rely heavily on juxtaposition and often lack grammaticalized coordination or acquire it through language contact (Mithum 1988). The density of additive marking in the French speeches does convey a literary impression as well as a degree of formality that is less striking in the more conversational-sounding English ones. This is no doubt a reflection of the greater distance between literary and conversational French than is the case for English. Additive markers combine with other coherence markers to form a network that knits the discourse together into a tightlystructured whole. In the English speeches, by contrast, additive discourse relations are more often left implicit, and the resulting discourse is more loosely woven.

As seen in Section 2, markers of consonant discourse relations are expected to be relatively infrequent because discourse coherence can be established by juxtaposition within a logical ordering. These most frequent French markers, however, seem to function in this genre as textstructuring devices marking information flow more than as relational propositions. In political discourse, a regular filling of this French discourse-marker 'slot' seems almost obligatory. The French markers are more frequent, more bleached and arguably more grammaticalized than their English counterparts.

Further research will need to situate discourse marking in this genre with respect to other genres and discover to what extent the discourse constructions frequent in political speeches are used across other genres, and how these constructions may be evolving.

\section{Note}

1. Translation agencies regularly advise their clients that the 'expansion rate' in translation from English to French is 
between $15 \%$ and $20 \%$ by word count. See, for example, <http://www.kwintessential.co.uk/translation/articles/ expansion-retraction.html >, <http://translation-blog.trustedtranslations.com/prices-according-to-source-word-count2010-02-25.html>, <https://e2f.com/203/> and <http://www.andiamo.co.uk/resources/expansion-and-contractionfactors>. Conversely, translations from French to English are shorter by word count. Armstrong (2015) discusses "the high expansion rate usually seen in translation from English to French" (Armstrong 2015:193).

\section{References}

Aijmer, Karin 2007. Modal adverbs as discourse markers. A bilingual approach to the study of indeed. In Jochen Rehbein, Christiane Hohenstein and Lukas Pietsch (eds), Connectivity in Grammar and Discourse, 329-344. Amsterdam: John Benjamins.

Aijmer, Karin. 2008. The actuality adverbs 'in fact', 'actually', 'really' and 'indeed' - establishing similarities and differences. In Martin Edwardes (ed.) Proceedings of the BAAL Conference 2007, 111-120. London: Scitsiugnil Press.

Aijmer, Karin and Anne-Marie Simon-Vandenbergen. 2007. The semantic field of modal certainty. A corpus-based study of English adverbs. Berlin: Mouton de Gruyter.

Armstrong, Nigel. 2015. Culture and translation In Farzad Sharifan (ed.) The Routledge Handbook of Language and Culture, 181-195. London: Routledge.

Asr, Fatemeh Torabi and Vera Demberg 2012. On the information conveyed by discourse markers. Proceedings of the Workshop on Cognitive Modeling and Computational Linguistics, Sofia, 08 August 2013, 84-93. Association for Computational Linguistics.

Bertin, Annie. 2002. L'émergence du connecteur en effet en moyen français. Linx, 46: 37-50

Charolles, Michel and Benjamin Fagard. 2012. 'En effet' en français contemporain : de la confirmation à la justification/explication. Le Francais Moderne: 137-164.

Chuquet, Hélène and Michel Paillard. [1987] 1989. Approche linguistique des problèmes de traduction anglais $<>$ français, revised edition. Paris: Ophrys.

Couper-Kuhlen, Elizabeth and Sandra A. Thompson. 2000. Concessive patterns in conversation [with Sandra A. Thompson]. In Elizabeth Couper-Kuhlen and Bernd Kortmann (eds.), Cause, Condition, Concession, Contrast: Cognitive and Discourse Perspectives, 381-410. Berlin: Mouton de Gruyter.

Danlos, Laurence, Margot Colinet and Jacques Steinlin. 2015. FDTB1, première étape du projet « French Discourse Treebank» : repérage des connecteurs de discours en corpus. Discours 17. http://discours.revues.org/9065 ; DOI : $10.4000 /$ discours.9065.

Dictionnaire des synonymes français. Digital resource developed by the CNRS, University of Lyon 1 and University of Caen. http://dico.isc.cnrs.fr/dico/fr

Dictionnaire Le Robert \& Collins français-anglais et anglais-français. 2013. Editions Le Robert.

Fetzer, Anita and Marjut Johansson. 2010. Cognitive verbs in context. In Stefania Marzo, Kris Heylen and Gert De Sutter (eds.) Corpus Studies in Contrastive Linguistics, special issue of the International Journal of Corpus 
Linguistics 15(2): 240-266.

Gallagher, John D. 1995. L'effacement des connecteurs adversatifs et concessifs en français moderne. In Michel Ballard (ed.) Relations discursives et traduction, 201-220. Lille: Presses Universitaires de Lille.

Guillermin-Flescher, Jacqueline. 1981. Syntaxe comparée du français et de l'anglais. Problèmes de traduction. Paris: Ophrys.

Halliday, Michael A.K. 1994. An Introduction to Functional Grammar. London: Edward Arnold.

Hasselgård, Hilde. 2014. Additive conjunction across languages: 'dessuten' and its correspondences in English and French. In Signe O. Ebeling, Atle Grønn, Kjetil Rå Hauge and Diana Santos (eds), Corpus-based Studies in Contrastive Linguistics. Oslo Studies in Language, 6(1): 69-89.

Hobbs, Jerry R. 1985. On the Coherence and Structure of Discourse, Report No. CSLI-85-37, Center for the Study of Language and Information. Stanford, CA: Stanford University.

Holmes, Janet 1994. Inferring language change from computer corpora. ICAME Journal 18: 27-40.

Levy, Roger and T. Florian Jaeger. 2007. Speakers optimize information density through syntactic reduction. In B. Scholkopf, J. Platt, \& T. Hoffman (eds.), Proceedings of the Twentieth Annual Conference on Neural Information Processing Systems, 849-856. Cambridge, MA: MIT Press.

Lewis, Diana M. 2005. Mapping adversative coherence relations in English and French. In Karin Aijmer, Hilde Hasselgård and Stig Johansson (eds) Contrast in Context. Special issue of Languages in Contrast 5(1): 33-48.

Mann, William C., and Sandra A. Thompson. 1986. Relational propositions in discourse. Discourse Processes 9(1): 57-90.

Mason, Ian. 2001. Translator behaviour and language usage: Some constraints on contrastive studies. Hermes 26: 65-80.

Mithun, Marianne. 1988. The grammaticalization of coordination. In J. Haiman and S. A. Thompson, Clause combining in grammar and discourse, 275-329. Amsterdam: John Benjamins.

Murray, John D. 1997. Connectives and narrative text: The role of continuity. Memory and Cognition 25(2): 227-236.

Nùñez Pertejo, Paloma. 2008. The multifunctionality of 'indeed' in contemporary spoken and written English. English Studies 89: 716-736.

Oberlander, Jon and Johanna D. Moore 2001. Discourse cues: Further evidence for the core contributor distinction. Cognitive Linguistics 12(3): 317-332.

Patterson, Gary and Andrew Kehler 2013. Predicting the presence of discourse connectives. In Proceedings of the conference on Empirical Methods in Natural Language Processing EMNLP, 914-923. Association for Computational Linguistics.

Quirk, Randolph, Sidney Greenbaum, Geoffrey Leech and Jan Svartvik. 1985. A Comprehensive Grammar of the English Language. London: Longman.

Roget's Thesaurus, online at http://www.roget.org/.

Rossari, Corinne. 2016. L'approbation dans un dialogue devient-elle une concession dans un monologue ? Etude de 'certes', 'en effet', 'effectivement', 'd'accord', 'OK'. In Laure Sarda, Denis Vigier and Bernard Combettes (eds.) 
Connexion et indexation. Ces liens qui tissent le texte. Mélanges pour Michel Charolles. Lyon: ENS Éditions. http://books.openedition.org/ enseditions/6847.

Roze, Charlotte. 2009. Base lexicale des connecteurs discursifs du français. Master's dissertation, University of Paris Diderot.

Schoonjans, Steven. 2012. Topologie contrastive des particules de démodulation. Comparaison de l'allemand et du français. Leuven Working Papers in Linguistics (1): 62-76.

Schoonjans, Steven. 2014. Oui, il y a des particules de démodulation en français. CogniTextes 11.

Simon-Vandenbergen, Anne-Marie and Karin Aijmer. 2007. The Semantic Field of Modal Certainty. A Corpus-based Study of English Adverbs. Berlin: Mouton de Gruyter.

Taboada, M. 2009. Implicit and explicit coherence relations. In Jan Renkema (ed.) Discourse, of course, 125-138. Amsterdam: John Benjamins.

Traugott, Elizabeth C. and Richard Dasher, 2002. Regularity in Semantic Change. Cambridge: Cambridge University Press. 